\title{
Inflation and the Economic Recovery
}

\author{
ROGER W. SPENCER
}

T

HE recovery is solid. That unfortunate combination of falling output and rising rates of price increase which characterized the latest recession has been sharply reversed. There remains sufficient capacity for output gains to continue for some time, but many observers are monitoring price data and policymakers' actions closely for any signs which might foreshadow a resumption of inflationary pressures.

This article first compares the current recovery to others in the recent past and then describes the two chief factors responsible for the economic progress observed heretofore: moderate stabilization policies and the absence of adverse structural shocks. The interaction of these factors with inflation and inflationary expectations is analyzed in the final section of the article. It is argued that the abatement of inflation and inflationary expectations is an important element in assessing the likelihood of long-lasting economic prosperity.

\section{THE RECOVIEY TO DATE}

Up to the present time, the economic recovery, although not exceptional when measured against other recovery periods, has been stronger than anticipated by most analysts. Only a short time ago, it was claimed in many quarters that because of the severe shocks dealt to the economy in the form of unexpected

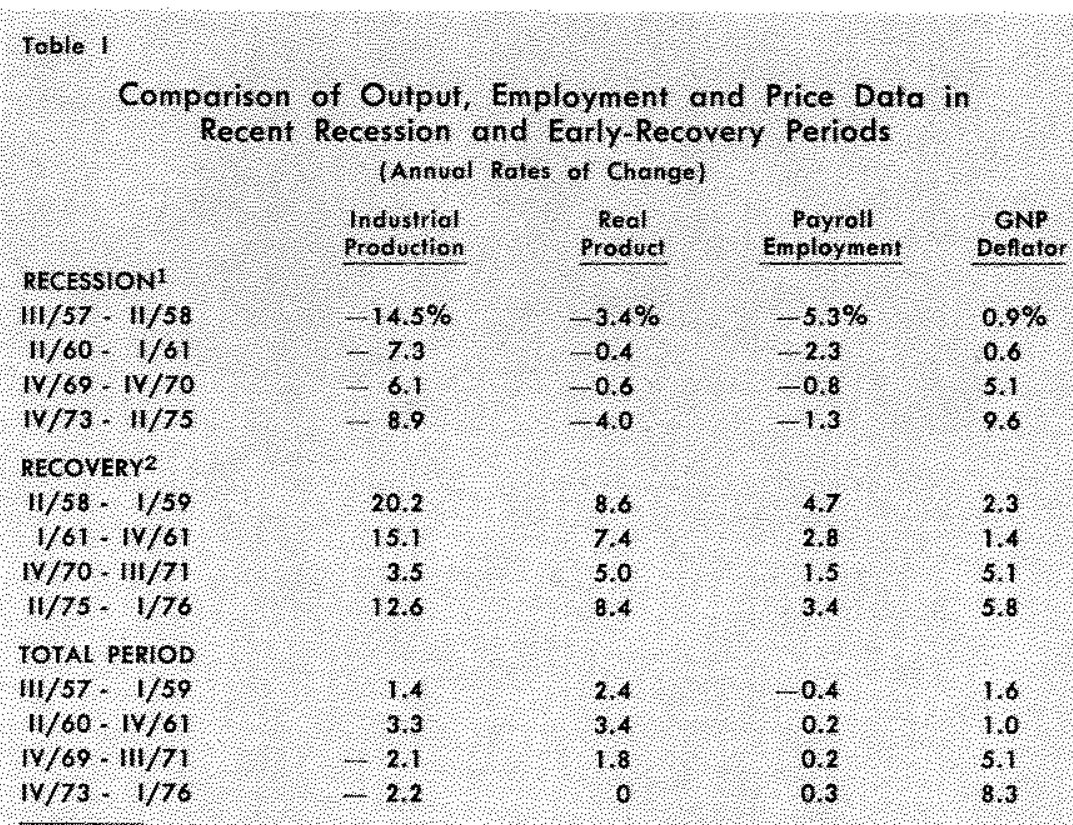

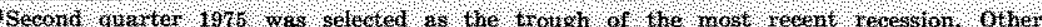

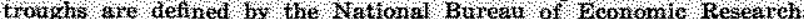

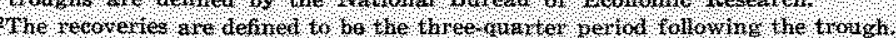

increases in the cost of energy, liquidity crises and political turmoil, exceptional monetary and fiscal stimuli would have to be applied to get the economy turned around. Growth rates of the money supply (M1) of 10 to 15 percent were advocated as a desirable stimulant to economic activity. ${ }^{1}$ Such actions were never taken and yet the recovery has moved smoothly into high gear.

\footnotetext{
'See, for example, U. S. Congress, Hearings Before the Joint Economic Committee, The 1975 Economic Report of the President, 94th Cong., 1st sess., February 5, 6, 7 and 14 , $1975, \mathrm{p}, 548$.
} 


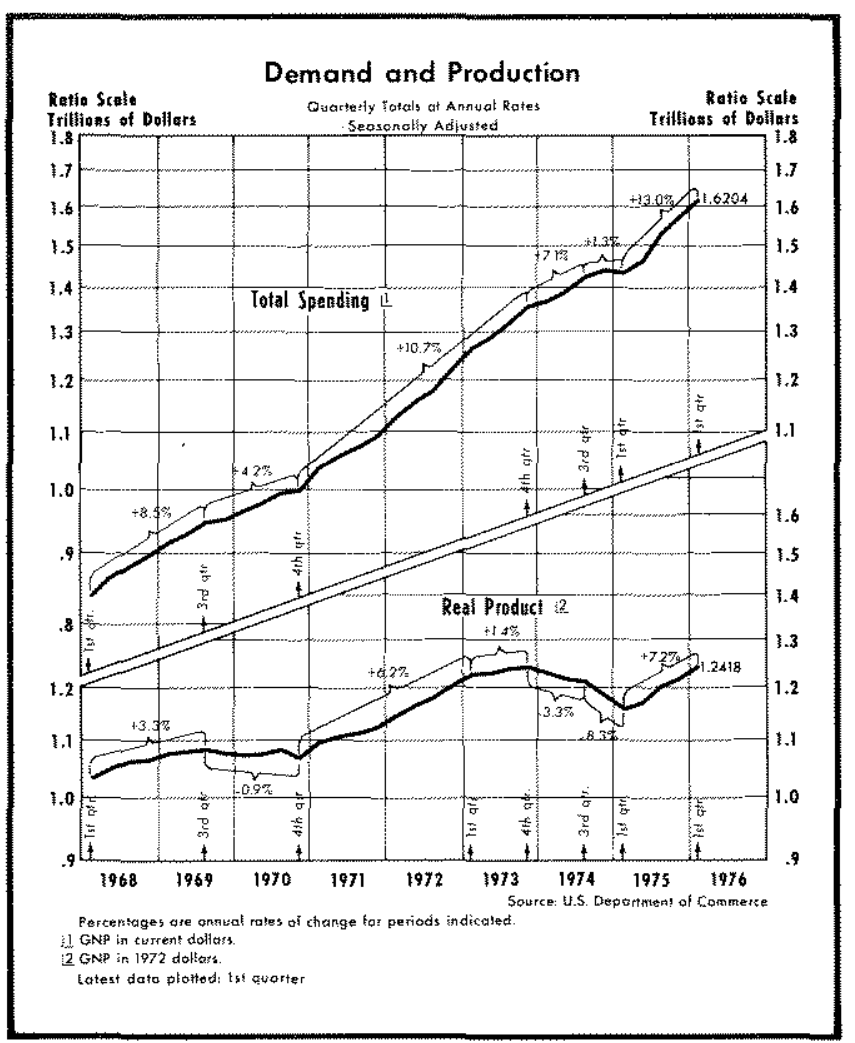

\section{Output, Employment, and Prices}

Table I indicates that output and employment increased rapidly over the past three quarters, about in line with similar periods following earlier recessions. The rebound has been more vigorous than following the 1969-70 recession, and roughly similar to the first three quarters following the two earlier recessions.

Employment gains have been sufficiently strong relative to labor force growth to push the unemployment rate down from a high of 8.9 percent in May 1975 to the 7.3 percent rate observed one year later. Industrial production growth, which has been most pronounced in the consumer goods area, has been steady but unspectacular throughout the recovery. Reported capacity utilization of major materials rose from 70.9 percent last spring to 80.7 percent in the first quarter of this year.

Prices have increased at a more rapid rate in this recovery than in others. Only the 5.1 percent rate of increase in the first three quarters following the 1970 recession is at all comparable to the 5.8 percent rate of increase in the three quarters ending first quarter 1976. Of course, prices rose at a far more rapid pace during the latest recession than during others. Note also the 8.3 percent rate of increase of prices over the latest total recession/recovery period.

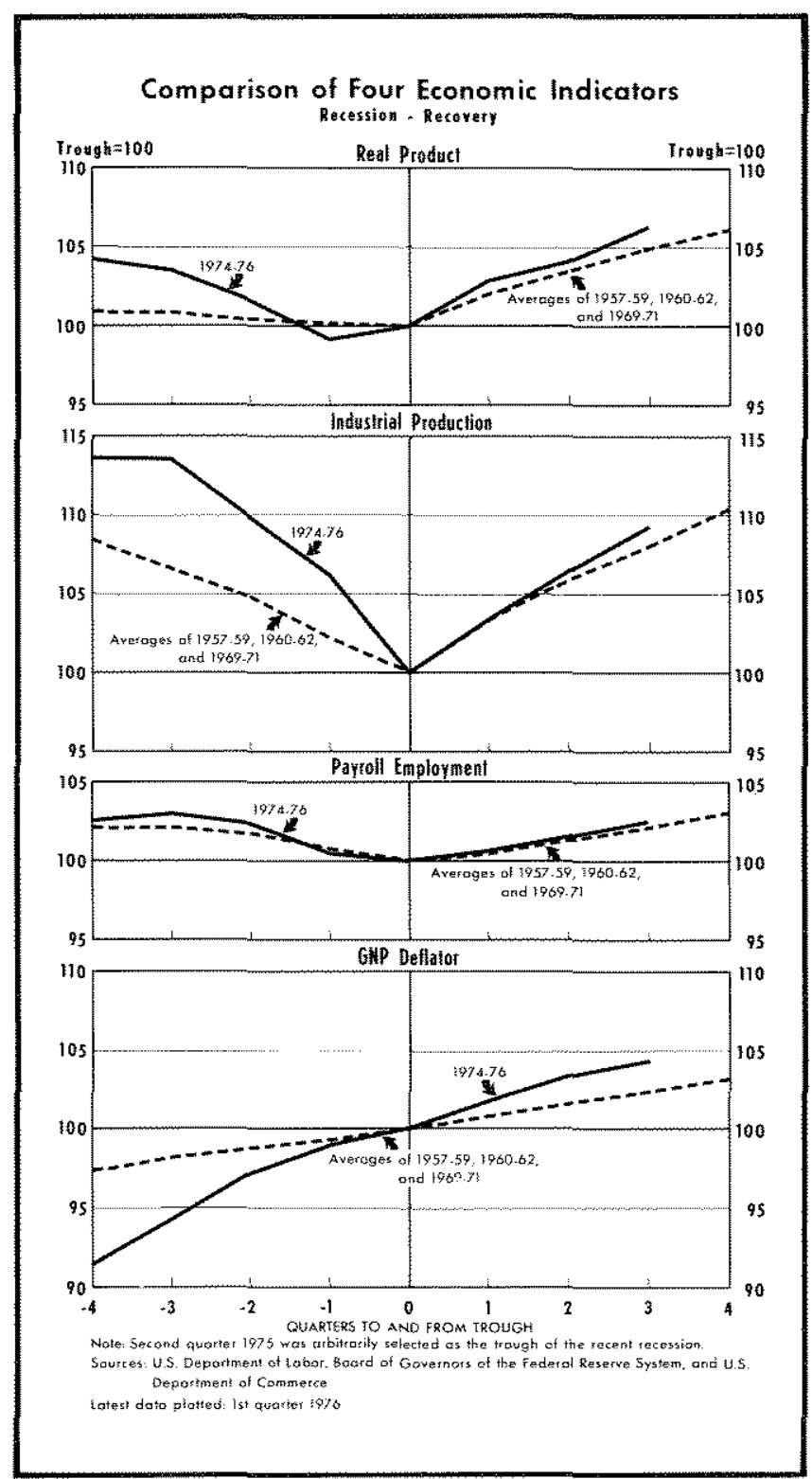

\section{Sectoral Activity}

The recovery has not been unusual in terms of the pattern of growth of most economic sectors. Consumer spending has provided much of the good economic news since early 1975. Retail sales, especially automobile sales, have been impressive. Yet, as indicated in Table II, consumption for the latest total recession and recovery period has not increased quite as rapidly as in any other comparable period.

Government spending has not expanded by an exceptional amount relative to previous recession/recovery periods. The Table indicates that housing expenditures, although increasing at a moderate pace in the latest recovery, remain far below spending levels reported in 1973. Plant and equipment ex- 


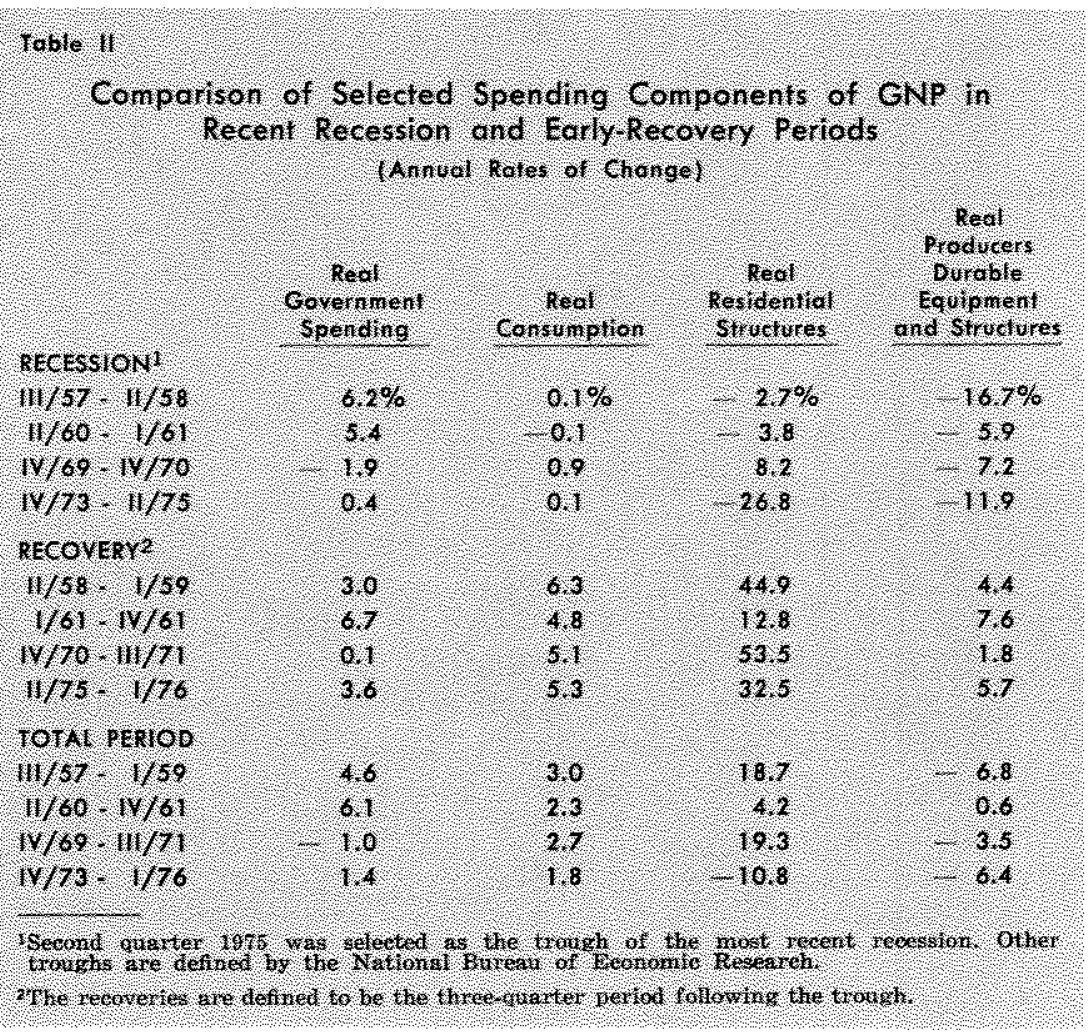

\section{Srablization Poncter}

The growth of monetary aggregates and the level of interest rates are associated closely with monetary actions. The Federal deficit and tax and expenditure functions are representative fiscal indicators.

Monelary Actions - The monetary base, the primary determinant of money supply (Ml) trend growth, has increased at a fairly steady 6 to 8 percent rate since 1970. However, M1 has fluctuated considerably around its trend growth in recent years. Changes in the demand for currency and time deposits relative to demand deposits have been chiefly responsible for the fact that MI slowed from about a 6 percent trend growth to a 3 percent rate from second quarter 1974 to first quarter 1975 , rose at a 7.4 percent rate over the next two quarters, and fell to a 2.5 percent rate of increase in the two quarters ending first quarter 1976. The latest available penditures, which picked up considerably in the first quarter of 1976, have been weaker over the latest total recession/recovery period than in any other period, with the exception of 1957-59.

\section{SOURCES OF THE RECOVERY}

In every recovery there are normal cyclical forces which support the upward impetus given the economy by outside, or exogenous, forces. For example, if the recession has been a severe one, many key workers such as foremen and skilled tradesmen would have lost their jobs. As the economic situation improves, however, these individuals generally will be the first to be rehired, and will make significant contributions to the production process. The same is true of equipment. The best, most efficient equipment will be the last to stop running as the recession deepens, but the first to be brought back into operation as the upswing begins. In short, the nature of the business cycle itself is conducive to increased productivity, efficiency, and output in the early stages of a business upturn.

Apart from cyclical forces, there are two major factors which have contributed to the latest upturn in economic activity: moderately expansive stabilization policies and the absence of adverse structural shocks. data indicate that growth of both the monetary base and the money supply have picked up sharply in recent months.

On balance since the Federal Reserve declared its one-year target range of $\mathrm{Ml}$ growth in March 1975 to be 5 to 7.5 percent, the rate of growth of money has been near the lower end of the range, increasing about 5 percent from first quarter 1975 to first quarter

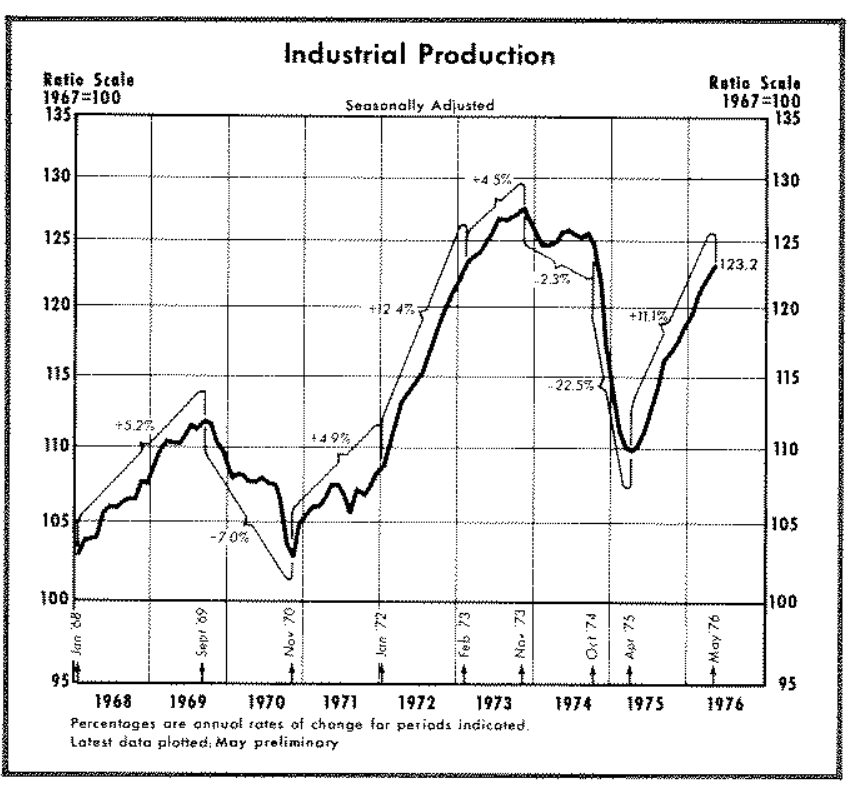




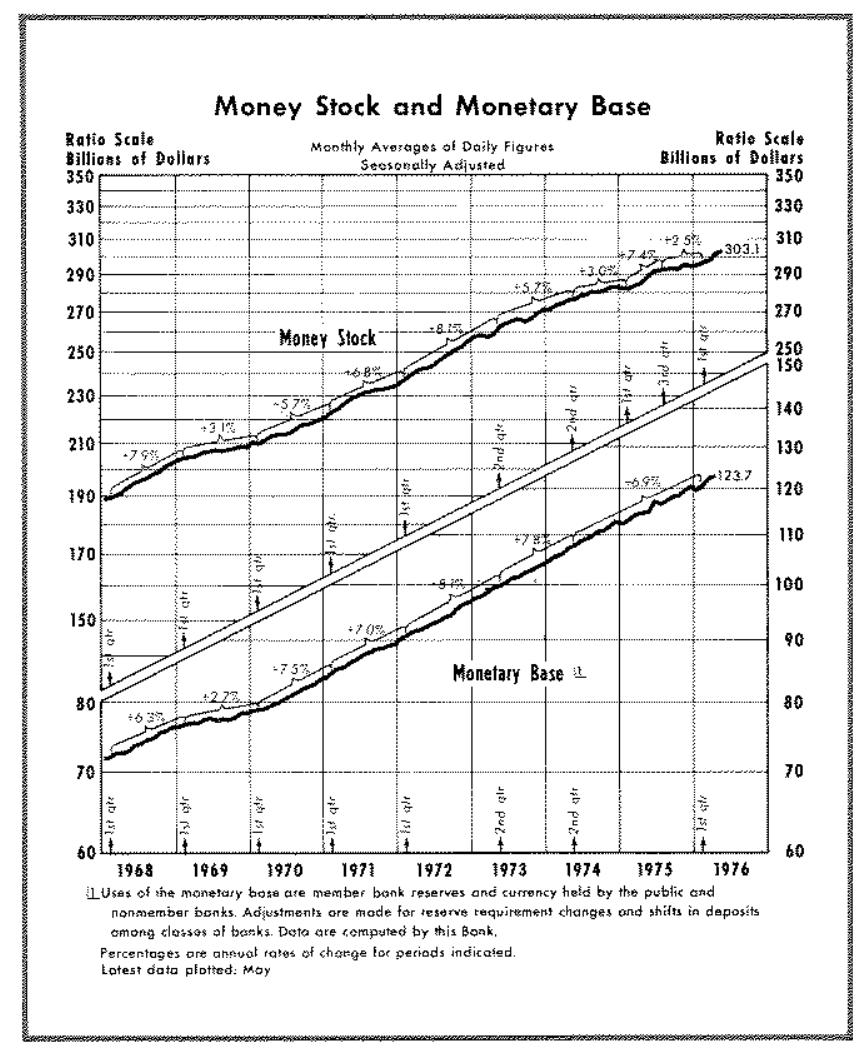

1976. Over the past year the Federal Reserve has shifted its base periods and targets somewhat, the latest declared target range being 4.5 to 7 percent growth from first quarter 1976 to first quarter 1977.

M2 (M1 plus net time deposits) growth, athough subject to some fluctuations, has been close to the range of 8.5 to 10.5 percent targeted by the Federal Reserve in March 1975. M2 increased 9.5 percent in the year ending first quarter 1976, about the same as its trend rate over the first several years of the current decade.

Both long- and short-term interest rates fell unevenly from their 1974 peaks, although such rates have moved up somewhat in recent weeks. The fall in rates accompanied, to some extent, the slowing in real economic activity in 1974 and the decline in the rate of inflation which began in 1975. There is little evidence that the Federal Reserve was actively trying to push down short-term interest rates through excessive money supply growth during this latest recovery period. The published records show that for the most part in 1975, the Federal Reserve adopted policies in which the Federal funds rate was to be kept in a range consistent with moderate money supply growth.

Fiscal Achons - L Last year the Congress instituted a new budget process designed to bring Federal

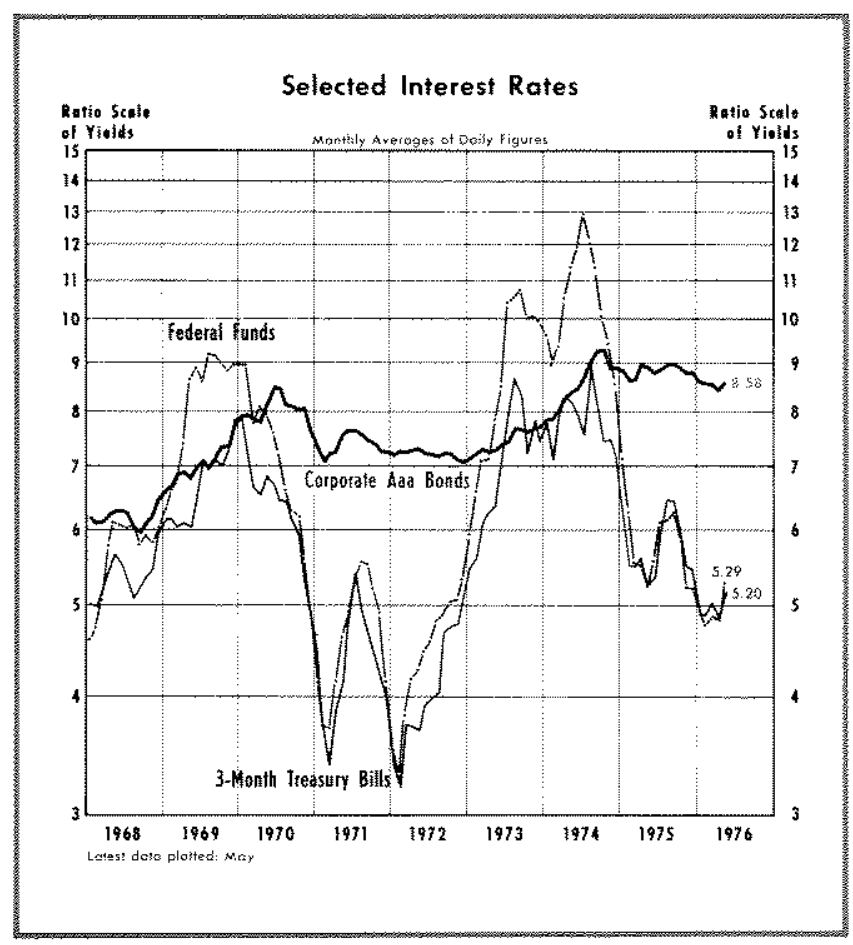

spending under closer control. Despite one of the largest budget deficits in history, many observers contend that significant progress was made under the Congressional Budget Act of 1974 toward getting the Congress to approach the budget process in a broader, more responsible manner than in the piecemeal fashion which prevailed previously.

In the year ending June 1976, the budget deficit (on a unified budget basis) is expected to be about $\$ 76$ billion. This figure compares with the $\$ 43.6$ billion deficit experienced in the preceding year. Currently, the President and Congress are attempting to set the budget for fiscal year 1977 which begins October 1, 1976 and runs through September 30, 1977. The President's announced expenditure target of $\$ 394.2$ billion would amount to only a 5.5 percent rise over the previous year, the smallest year-to-year increase since 1969. Combined with the President's expectations of tax revenues in fiscal year 1977, the expenditure figure, if attained, would give a budget deficit of about $\$ 43$ billion.

Congress target of $\$ 413.3$ billion is consistent with a 10.7 percent growth in expenditures, a figure lower than the 1975 and expected 1976 percentage increases. These data do not include expected outlays of about $\$ 98$ billion for the "transitional quarter," a period between July 1, 1976 and September 30, 1976. Inclusion of this big jump in expenditures gives fiscal policy a more expansive look. Moreover, it should be noted that so-called "off-budget" ontlays, which receive little 
public attention, have been rising at a rapid rate, and must be watched more closely than in the past.

Despite the generally perceived trend toward fiscal responsibility, there is concern that governmental "crowding out" of the private sector will become a more serious problem as private demand continues to pick up. One way in which crowding out occurs is through the capital market route. The government's demand for funds competes with private sector demands for funds, and those private sectors which are most responsive to rising market yields are most likely to be crowded out. Two rather interest-sensitive sectors are housing and private capital spending, neither of which has bounced back from the recession as strongly as anticipated by many analysts.

\section{SHruchural Factors}

Since August 1971, the economy has been subjected to an unusual series of destabilizing shocks. Beginning with the imposition of price and wage controls in August 1971 and going through the recent liquidity crises of various governmental and nongovernmental organizations, the wide variety of shocks administered and overcome is a testimonial to the considerable resiliency of the U. S. economic system. The reduced frequency of such shocks over the past year has permitted cyclical and policy forces to promote the normal recovery so far observed. Some of these shocks are described below.

Energy-Energy price levels remain high, but rates of change have about stabilized. The embargo of autumn 1973 and subsequent fotrr-fold rise in oil prices adopted by the oil cartel contributed significantly to the one and one-half years of recession. Prices and employment in and outside the energy sector were adversely affected for quite some time. Oil came to cost the United States much more in terms of currently produced goods and services as well as in terms of goods and services to be produced in the future.

An energy bill was passed by Congress and signed by the President in late 1975. This legislation forced down prices of some domestically produced oil and authorized oil de-regulation to begin in thirty-nine months. These actions will probably keep oil prices down briefly, but in the absence of prompt, certain de-regulation, will do little to encourage greater domestic production and lower energy prices over a sustained period.

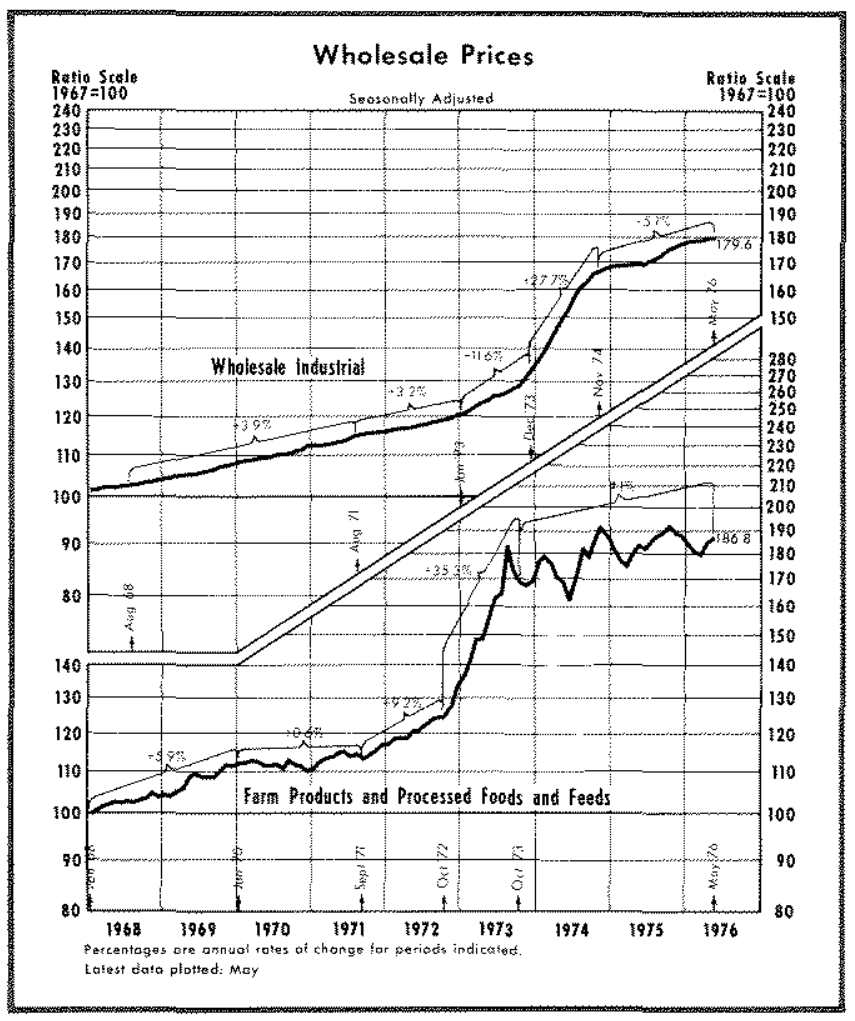

Agriculture - During the period of the recovery, the food-supplying sector of the U. S. economy began to recover from a battering series of agricultural setbacks which occurred for about two years beginning in 1972. Floods, droughts, blizzards, and other misfortunes combined to foster sharply higher prices for meats, poultry, grains, soybeans, and fish. As with the energy situation, most nations of the world were affected in one way or another by the unfortunate developments in the food sector.

Although food short-falls promoted huge price increases, these increases in turn encouraged the production of more agricultural products. Moreover, unlike the reaction to oil price increases, government policies were swiftly altered to stimulate the production of more, not less, agricultural products. The suspension of wheat acreage allotments and controls on meat imports are two examples of such policies. Food supplies rose so rapidly that wholesale prices of farm products and processed foods and feeds in May 1976 were actually below the level attained in November 1974.

Mandalory Controls - The normal and desirable reaction of the economy to the above shocks would be changes in relative prices - that is, changes in the price of an individual commodity relative to the average price of all other commodities. However, this process was hampered by the existence of actual, 


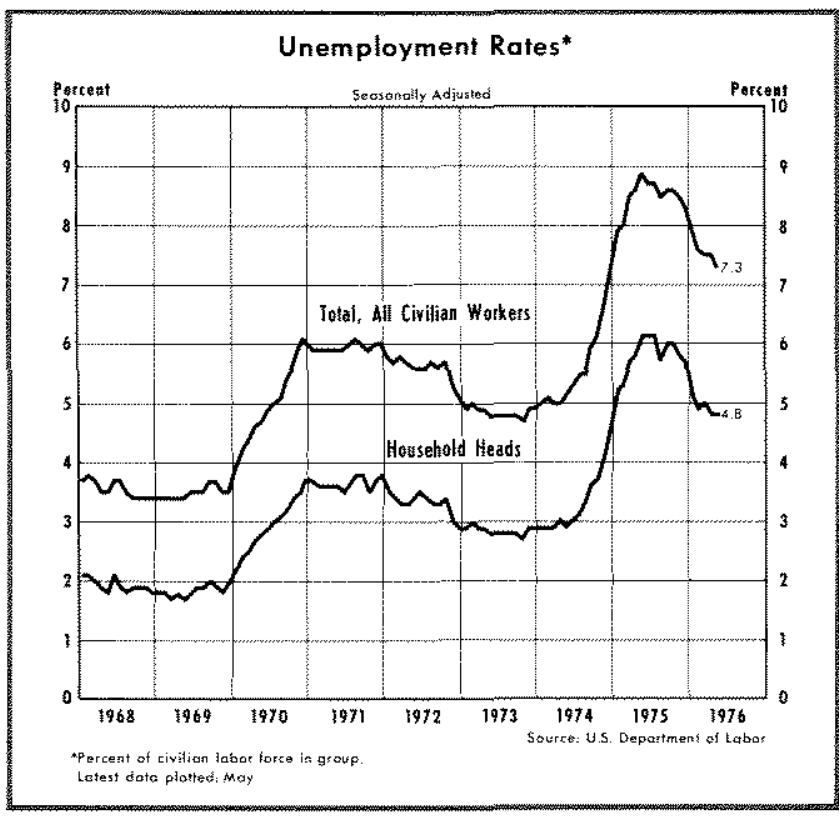

and fear of future, price and wage controls. Peacetime price and wage controls were adopted for the first time in August 1971. For a brief period, the controls held measured prices and wages below what they otherwise would have been, but the associated inequities and inefficiencies were so great as to require their removal. The initial positive effects of the controls were soon reversed, as workers and firms attempted to get their wages and profit margins as high as possible in case another round of controls were to be instituted. A jump in price levels and greater unemployment were the predictable results of the "reverse" wage and price control effort.

The specter of controls, however, has diminished with each passing month of relative price and wage stability. Only the Council on Wage and Price Stability continues as a reminder. Fortunately, this agency has been as interested in halting the supply-restrictive measures of government organizations as it has been in directly monitoring wages and prices.

Govemment Regulations - In recent years all business organizations have become subject to a growing maze of government regulations. ${ }^{2}$ Older agencies, such as the Interstate Commerce Commission, Federal Communications Commission, and the Federal Aviation Agency, which regulate specific industries, have been joined in the past several years by new agencies whose rulings apply to much broader cate-

2See Murray L. Weidenbaum, Government-Mandated Price Increases: A Neglected Aspect of Inflation (Washington, D. C.: American Enterprise Institute for Public Policy Research, 1975) gories of business firms. Prominent examples are the Occupational Safety and Health Administration, the Environmental Protection Agency, the Equal Employment Opportunity Commission and the Consumer Product Safety Commission. Each of these wellintentioned agencies was created by Congress to correct a specific problem area, but an undesirable side effect has been the shift of resources away from the production of capital and consumer goods and services toward the production of regulatory services.

The resources of virtually every firm in the nation have been affected by the necessity of acquiring knowledge of each new regulation and the burden of meeting the increased paper work demands. To cite three individual cases, there is evidence that: several hundred foundries in the United States were closed over the past few years because they could not meet EPA and OSHA regulations; the steel industry will have to allocate more than one-fourth of its capital expenditures from 1975 to 1983 to pollution control equipment; firms could be required to invest about $\$ 31$ billion to meet the 85 decibel noise level the EPA has recommended as a maximum limit in work areas. ${ }^{3}$ These examples suggest the breadth of the regulatory shocks to which firms have recently been and are being subjected. In many cases the costs to businessmen are passed along to consumers in the form of higher prices to cover higher resource costs. The inflationary impact will be even greater in the future if capital formation is significantly affected. ${ }^{*}$

Liquidity Crises - The recession sharply accentuated the difficulties of institutions controlled by poor, corrupt, or "unlucky" management and subject to cash flow problems. In a short period of time such major firms as Lockheed, Penn Central, and Equity Funding either neared or went into bankruptcy. Franklin National Bank failed; in fact, 13 banks collapsed in 1975. There had not been more than nine bank failures in any one year since 1942. In addition, New York City's financial plight served to call atten-

\footnotetext{
3See "Pollution Control: High Operating Costs Seen Boosting Steel Price $\$ 25$ to $\$ 30$ a Ton by $1983,{ }^{\text {," Daly Report for }}$ Executives, 14 May 1975, p. A-13; "Where Overregulation Can Lead: An Interview with Dr. Murray L. Weidenbaum," Nation's Business (June 1975), p. 29; "Regulators: A Rising Clamor Over Noise Limits," Business Week, 30 June 1975 , p. 34 .

tLeonall C. Andersen, "Is There a Capital Shortage: Theory and Recent Empirical Evidence (Paper presented before the Joint Meeting of the American Finance Association and the American Economic Association, Dallas, Texas, December $28,1975)$. Andersen contends that a negative relation indeed exists between these types of govermment regulation and capital formation.
} 
tion to the less than robust financial condition of a large number of state and local governments around the country.

Fortunately, the recovery has pushed up real profits and equity prices, permitting many firms to avoid debt-financing while restructuring their asset and liability positions. Cash flow has also improved significantly at the state and local government level, as tax revenues have improved and governmental bodies have cut back the rate of expenditure increase. Dire predictions of the imminent collapse of the U.S. financial system have been shown to be premature.

International Economic Developments - Along with price and wage controls came another shock in August 1971 - the U. S. Government's decision to halt the convertibility of dollars into gold. Subsequently, there occurred two official devaluations of the U. S. dollar, and an international move toward freely floating exchange rates. The implications of these developments were further muddled by the payments problems associated with the oil cartel's new-found wealth and the U. S. Government's decision to sell gold to private citizens. Given the degree of change that these events brought to the international payments system, fears arose that the worldwide financial system was on the verge of collapse.

Thus far, the international monetary system has held up remarkably well. Despite the fact that serious problems remain, the issues regarding gold, flexible exchange rates, and disposition of oil profits are being worked out in various markets with surprising dispatch.

Summary - The policy and structural factors discussed above combined so as to precipitate the worst recession in the postwar era. Rapid price increases during this period contributed to uncertainty and expectations of further price increases. With the slowing in price increases which began more than a year ago, many observers have gained confidence in the durability and strength of the current recovery. The following section of this article develops the inflation issue in more detail in order to shed light on the future course of economic activity.

\section{TNHLATON AND INLLATONARY EXPECTATIONS}

There is an underlying trend of inflation even in the absence of substantial structural changes such as those described above. This trend is determined pri- marily by domestic monetary and fiscal policy actions. Most analysts believe the current underlying trend to be about 5 to 6 percent, approximately the same as the trend growth of Ml. Policy actions influence the price trend by affecting the demand for goods and services, given a stable underlying growth of supply or potential output. Most structural wrenching of the economy, on the other hand, directly affects the supply of goods and services, and with given demand, causes volatile short-run price fuctuations.

Fiscal and monetary policies represent the "macro" approach to serious economic problems. Altering such policies affects the demand for all goods and services. A reduction in the supply of a particular good, such as oil or soybeans, constitutes a "micro" economic problem, which is best corrected by micro or structural economic policies. One result of a decline in the supply of oil or soybeans is a rise in the price of oil or soybeans relative to other goods. All that a stimulative monetary or fiscal policy could do, in such cases, is push up the absolute price of all goods and services, leaving the relative price of oil and soybeans unchanged. However, a structural policy oriented toward increasing the supply of oil or soym beans could bring the relative prices of these commodities back into alignment. ${ }^{5}$

During the period in which relative prices of goods and services are adjusting toward some equilibrium value, relative rates of return on labor and nonlabor inputs are also adjusting. Because there is not immediate adjustment of factors of production to changes in rates of return, unemployment of resources is typically associated with this adjustment period. Indeed, the sharp rise in unemployment in 1974 was largely due to the severe structural shocks absorbed by the economy over a relatively brief period of time. Policymakers, recognizing the limited ability of macroeconomic measures to eliminate structural unemployment, adopted policies of moderation. This has been more the case with regard to monetary than fiscal policy.

Why might these policies be considered appropriate? There are at least two explanations. One has to do with the effect of such policy actions on the economy independent of their effect on price anticipations and the other considers the impact with price anticipations.

\footnotetext{
5See the accompanying article by Denis $S$. Karnosky, "The Link Between Money and Prices - 1971-76," this issue of the Review.
} 


\section{Stmilatabe Poliches Assuming No price Expectations Elfech}

Ignoring for the moment the effect of stimulative policies on price expectations, what would be the implications of a doubling of both the actual budget deficit and the rate of growth of the actual money supply? First, because the entire economy is and has been operating at less than capacity, unemployment would fall at a faster pace than it would fall under more moderate policies. Second, policymakers would soon face the necessity of reversing their stimulative policy actions. Given sharply declining unemployment, at what point should expansionary policies be curtailed -7 percent, 6 percent, 5 percent, 4 percent, or at a 3 percent aggregate unemployment rate?

The fact is that no one knows with any high degree of certainty the specific lags between policy change and unemployment response. Nor is it known with precision what rate of price increase is associated with a particular unemployment rate. Because aggregate unemployment measures of either labor or capital resources are comprised of sectors in which capacity utilization rates differ widely, shortages and rising wages and prices can emerge quickly in bottleneck areas under the lash of forceful macroeconomic policies. The capacity utilization measures themselves often give contradictory signals as to just how much slack exists at any time in the economy.

Finally, the track record of our policymakers in the postwar period is not good with regard to an awareness of when to cut back stimulative policies. In the early $1960 \mathrm{~s}$, prominent economists professed the belief that we had acquired the necessary knowledge and the tools to "fine tune" the economy with just the proper injection of, say, more government spend ing here and higher interest rates there. Historical experience with upward ratcheting inflation rates in the face of periodic recessions over the past fifteen years has shown that we have no such knowledge or that it has not been applied.

\section{Stmulatwe Policies Assumping "Polben \\ Anmowncement" Price Lxpectations Wheots}

In recent years the Federal Reserve has become more open in the announcement of its policy intentions. In addition, the Federal Government, to include the Congress, makes available for public scrutiny its specific budget policy preferences. Many observers believe there is an important linkage between policy statements, policy actions, and economic activity. Stimulative policy actions have come to be as- sociated with inflationary pressures and restrictive actions with periods of recession. Assuming that stated policy preferences bear some relation to policy actions, it is not too far-fetched to conjecture that an important segment of the public includes policy announcements as an input into its expectations of the future course of economic developments. In fact, a body of literature is currently being amassed which suggests that the public forms its expectations "rationally" on the basis of currently available economic information, which includes public policy pronouncements.

If we accept the notion that policy statements influence the expectation of future inflation, what impact would the announcement of, say, a money growth rate and a Federal deficit twice the actual declared targets, have had on such expectations last year? Quite likely, given past experience with deficits, money supply growth, and inflation rates, there would have been a marked rise in inflationary expectations. This could have been transmitted through the economy in numerous ways.

Mortgage and other lenders demand higher premiums when faced with the expectation of higher prices, thereby putting upward pressure on interest rates. Union and nonunion workers are placing greater emphasis on inflation escalator clauses in their negotiations; the anticipation of further price hikes could only strengthen their wage demands. Because firms were hit hard in recent years by the impact of inflation on profits due to their vulnerability to higher inventory costs and inadequate depreciation write-offs, corporate officials are among those most likely to give great attention to changes in macropolicies and policy statements. Such officials would likely attempt to protect themselves from the adverse effects of inflation, and conceivably, further price controls, by increasing prices.

With anticipations themselves forcing up prices, the stabilization authorities would have to continue any stimulative policy actions they might adopt in order to validate the price and wage hikes, or risk the outbreak of widespread unemployment by applying the monetary and fiscal brakes.

The long-rum effects of higher price anticipations are more difficult to forecast. There is little evidence that consumers, over the long rum, will spend more or that firms will invest more than otherwise in the face of rapid inflation. In fact, the likelihood is that so much energy and effort is put into beating inflation, that productivity is adversely affected. Lower productivity, given aggregate demand growth, means 
more inflation. In other words, there may be a vicious cycle associated with price anticipations, and the realization of such anticipations, which must be broken if the economic system is to continue to function in a viable manner.

\section{OUILOOK}

Economic activity has bounced back from the recent recession at a pace somewhat greater than other postwar recoveries, and stronger than anticipated by many analysts. Strongly expansionary policies were not required to spur the recovery because of the interplay of normal cyclical forces and the cessation of hamnful economic shocks. In fact, if price expectations are affected by current macrom economic policies, the adoption of moderate policy measures was conducive to a strengthened recovery.

The recovery should continue at a healthy pace for some time - in the absence of further shocks and given policies oriented toward eliminating structural deficiencies and curbing inflationary pressures. Some progress has been made by eliminating price and wage controls and by stimulating agricultural output, but not much has been done to further energy growth, or halt the growing network of government regulations.

So far as macroeconomic policies are concerned, firms must be convinced that they will not again be caught in an inflation-induced profit squeeze if they are to increase substantially their capital expenditures; and labor must be convinced that their wages will not be eaten up by rapid price advances if strikes and excessive wage settlements are to be avoided. Continued large deficits and the resumption of rapid monetary growth are inconsistent with such objectives. They are consistent with a return toward a path taken by a large number of inflation-plagued countries throughout the world.

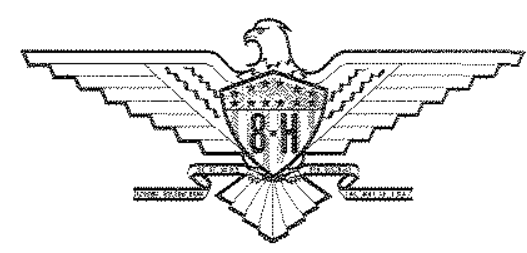

